Prepared in cooperation with the U.S. Fish and Wildlife Service

\title{
Vegetation of Lacassine National Wildlife Refuge, Louisiana: Recent Plant Communities with Comparison to a Three-Decade-Old Survey
}

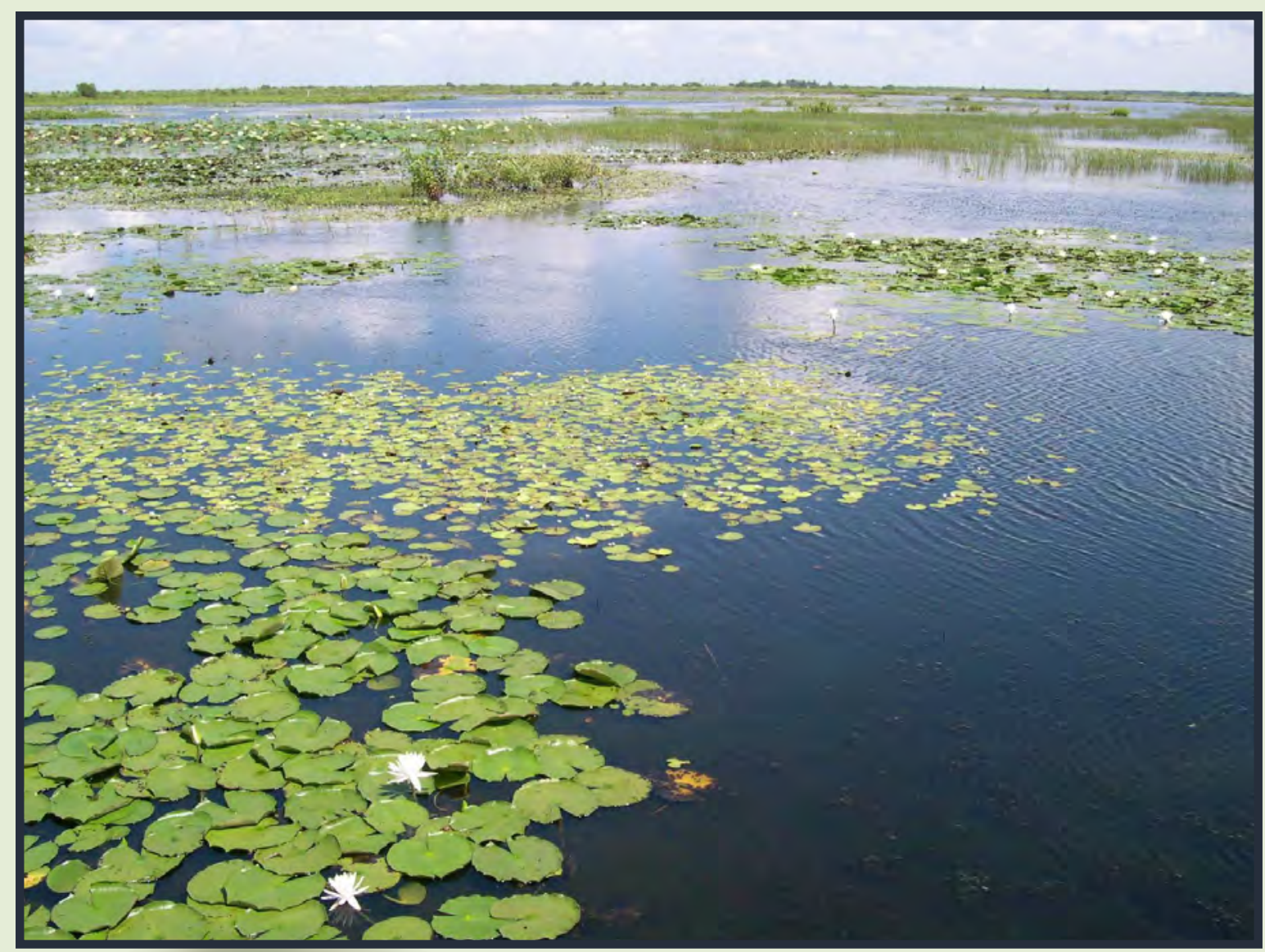

Scientific Investigations Report 2011-5174

U.S. Department of the Interior U.S. Geological Survey 



\section{Vegetation of Lacassine National Wildlife Refuge, Louisiana: Recent Plant Communities with Comparison to a Three-Decade-Old Survey}

By Rebecca J. Howard, Thomas C. Michot, and Larry Allain

Prepared in cooperation with the U.S. Fish and Wildlife Service

Scientific Investigations Report 2011-5174 


\section{U.S. Department of the Interior \\ KEN SALAZAR, Secretary \\ U.S. Geological Survey \\ Marcia K. McNutt, Director}

U.S. Geological Survey, Reston, Virginia: 2011

This and other USGS information products are available at http://store.usgs.gov/

U.S. Geological Survey

Box 25286, Denver Federal Center

Denver, CO 80225

To learn about the USGS and its information products visit http://www.usgs.gov/ 1-888-ASK-USGS

Any use of trade, product, or firm names is for descriptive purposes only and does not imply endorsement by the U.S. Government.

Although this report is in the public domain, permission must be secured from the individual copyright owners to reproduce any copyrighted materials contained within this report.

Suggested citation:

Howard, R.J., Michot, T.C., and Allain, Larry, 2011, Vegetation of Lacassine National Wildlife Refuge, LouisianaRecent plant communities with comparison to a three-decade-old survey: U.S. Geological Survey Scientific Investigations Report 2011-5174, 16 p. 


\section{Acknowledgments}

Funding for this study was provided by the U.S. Fish and Wildlife Service to Thomas Michot, who designed the study and implemented field data collection. Field assistance was provided by Melissa Collins, Barbora Kubátová, Wayne Norling, Wayne Syron, and Chris Wells. Assistance with plant identification was provided by David Rosen. We thank Darren Johnson, Five Rivers Services, LLC, for performing statistical analyses.

\section{Contents}

Acknowledgments .................................................................................................................ii

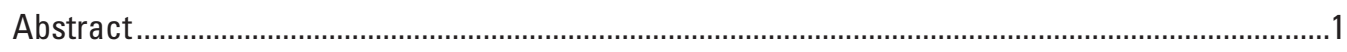

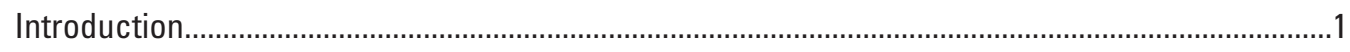

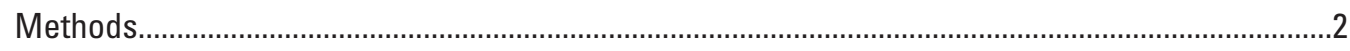

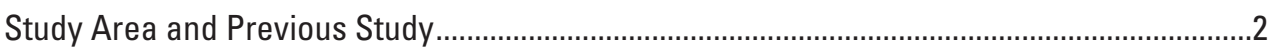

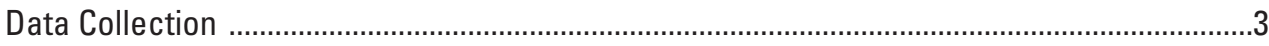

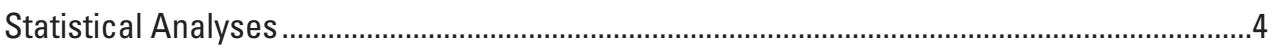

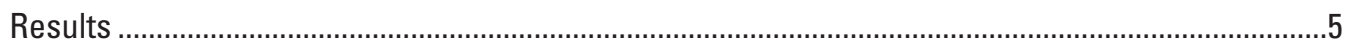

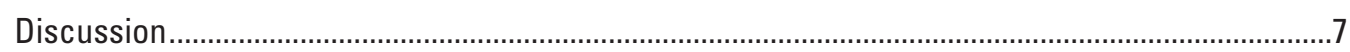

Vegetation Comparison Over Three Decades.....................................................................

Interannual Variation in Plant Communities ..............................................................................

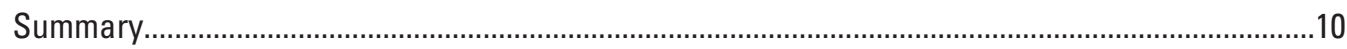

References Cited

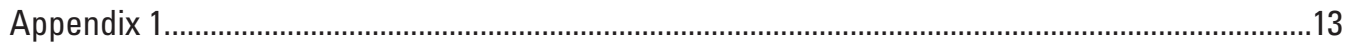

Appendix 2

\section{Figures}

1. Map of Lacassine National Wildlife Refuge, Louisiana .......................................................

2. Photographs of the two habitat types designated in 2006 in Lacassine pool, Lacassine National Wildlife Refuge, Louisiana .......................................................

3. Graphs showing daily rainfall at Lake Charles Regional Airport, Lake Charles, Louisiana, in 2006 and 2007 with sampling period each year indicated. 


\section{Tables}

1. Global Positioning System (GPS) locations for the southwestern corner of 14 sections established within Lacassine pool, Lacassine National Wildlife Refuge, Louisiana

2. Frequency and total cover of plant species identified in 2006 and 2007 in Lacassine pool, Lacassine National Wildlife Refuge, Louisiana

3. Frequency of plants identified by Fruge (1974) in 1973 in Lacassine pool, Lacassine National Wildlife Refuge, Louisiana

4. Significant results of a two-sample binomial test of species frequency, Lacassine pool, Lacassine National Wildlife Refuge, Louisiana, in 2006 and 2007

\section{Conversion Factors}

SI to Inch/Pound

\begin{tabular}{lll}
\hline \multicolumn{1}{c}{ Multiply } & By & \multicolumn{1}{c}{ To obtain } \\
\hline centimeter $(\mathrm{cm})$ & Length & \\
kilometer $(\mathrm{km})$ & 0.3937 & inch (in.) \\
meter $(\mathrm{m})$ & 0.6214 & mile (mi) \\
\hline & 1.094 & yard (yd) \\
\hline hectare (ha) & Area & \\
square centimeter $\left(\mathrm{cm}^{2}\right)$ & 2.471 & acre \\
square meter $\left(\mathrm{m}^{2}\right)$ & 0.001076 & square foot $\left(\mathrm{ft}^{2}\right)$ \\
square centimeter $\left(\mathrm{cm}^{2}\right)$ & 10.76 & square foot $\left(\mathrm{ft}^{2}\right)$ \\
hectare (ha) & 0.1550 & square inch $\left(\mathrm{ft}^{2}\right)$ \\
\hline
\end{tabular}

Horizontal coordinate information is referenced to the North American Datum of 1983 (NAD 83). 


\title{
Vegetation of Lacassine National Wildlife Refuge, Louisiana: Recent Plant Communities with Comparison to a Three-Decade-Old Survey
}

\author{
By Rebecca J. Howard, ${ }^{1}$ Thomas C. Michot, ${ }^{1,2}$ and Larry Allain'
}

\section{Abstract}

Shifts in plant community composition and structure can affect the quality of habitat for wildlife species. Lacassine National Wildlife Refuge in southwestern Louisiana was established in 1937 with a primary goal of providing habitat for wintering waterfowl species. A large freshwater impoundment constructed on the refuge to improve waterfowl habitat value was completed in 1943. About 10 years after construction was completed, staff at the refuge became concerned that emergent vegetation cover was increasing in the impoundment over time while open water areas, which are critical as foraging and resting areas for waterfowl, were decreasing. To document vegetation change over time, we collected information on plant community species composition for comparison to similar data collected in 1973. A total of 84 sampling plots was established in 2006 within the impoundment to coincide as closely as possible to plots sampled in the earlier study. Plant species composition and cover were recorded at each plot in the summers of 2006 and 2007.

Change between sampling events separated by more than three decades was determined by comparing the frequency of occurrence of 20 species identified in 1973 to their frequency in 2006 and 2007. Interannual variation was determined by comparing plot data between 2006 and 2007. In plots dominated by emergent vegetation, it was found that Bacopa caroliniana, Eleocharis equisetoides, Leersia hexandra, Panicum hemitomon, and Sagittaria lancifolia were significantly less frequent in 2006 and 2007 than in 1973.

The frequency of Brasenia schreberi, Cabomba caroliniana, Nitella gracilis, and Nymphoides aquatica was significantly lower in 2006 and 2007 than in 1973 in plots dominated by floating-leaved plants, submersed plants, or open water.

${ }^{1}$ U.S. Geological Survey, National Wetlands Research Center, 700 Cajundome Blvd., Lafayette, LA 70506.

\footnotetext{
${ }^{2}$ Current address; Institute for Coastal Ecology and Engineering, University of Louisiana at Lafayette, P.O. Box 43688, Lafayette, LA 70504.
}

In 2007, Hydrocotyle sp. and Sacciolepis striata were more frequent than in 1973 in emergent vegetation plots, and Utricularia sp. was more frequent in submersed or open-water plots. We documented interannual variation by an increase in species richness, the Shannon diversity index, and evenness of species distribution within plots in 2007 compared to 2006. The total cover by species did not differ between years, but the frequency of seven species was greater in 2007 compared to 2006 while the frequency of unvegetated surface was lower. Results indicated that the occurrence of some species varied between both 2006 and 2007 and 1973, but the lack of complete data from the 1973 study limits confidence in this conclusion. The interannual variation documented between 2006 and 2007 may be due to several factors, including a response to weather conditions or to recovery from the impacts of Hurricane Rita, which impacted Lacassine National Wildlife Refuge in the fall of 2005 and likely raised salinity levels in the impoundment. More information is needed to determine if the interannual variation identified in the plant communities of Lacassine National Wildlife Refuge between 2006 and 2007 was unusual or represents normal variation.

\section{Introduction}

Lacassine National Wildlife Refuge is located in the Mermentau Basin of southwestern Louisiana (fig.1) and encompasses about 14,200 hectares (ha) of freshwater marshes, bayous, and interspersed uplands. The refuge was established in 1937 with the primary objective of preserving high quality habitat for wintering waterfowl species. To enhance habitat values on the refuge, a 6,475-ha impoundment called "Lacassine pool" was completed in 1943. The pool is enclosed by an earthen dike system formed by using materials dredged from within and adjacent to the impoundment, and precipitation is the only water source (Fruge, 1974). Water levels in the pool can be lowered by gravitational flow through a system of three spillways with stop-log structures, but these structures do not allow complete drainage. By 1953, refuge personnel noted that vegetation cover within the pool was increasing while open water habitat, 
important for wintering waterfowl, was decreasing (Fruge, 1974). Increased cover of the emergent species Panicum hemitomon and Sagittaria lancifolia was of special interest because these species are considered low quality resting and foraging habitats for waterfowl. Concerns over the current condition of the pool habitat remain, with indications that waterfowl and fisheries habitat values have decreased over time in conjunction with the increase of emergent and submersed vegetation. As vegetation cover has increased, sediment surface elevation within the pool is believed to also have increased, and succession toward a palustrine scrub/shrub habitat is thought to be likely.

The impounded nature of Lacassine pool presents challenges for practical vegetation management. Many highvalue waterfowl food plants require permanent open water to persist and to expand in range, and high accretion rates in impounded wetlands may limit the extent of open water. Vertical accretion in wetlands results from the accumulation of organic matter and mineral sediment (Callaway and others, 1996). Because the pool is impounded, very little mineral sediment enters the system. Organic matter originating from plants growing in the pool, therefore, is the primary factor influencing sediment accretion in the pool system. Wetland plant growth and production are influenced by several factors, including herbivory, nutrient supply, flooding duration and depth, and salinity level. Accumulation of the organic matter produced by plants is affected by compaction and decomposition rate, which are in turn influenced by temperature, flooding, nutrient availability to decomposing organisms, and the quality of plant material (Mitsch and Gosselink, 2007). The feedback loop between plant production, flooding, and vertical accretion has been described by Nyman and others (1993). In open water areas of the pool, organic material has been noted to float to the water surface and become colonized by emergent plant species; these floating sections of marsh have been called "pop-ups" (Fruge, 1974). If these floating marsh sections persist, they may act to increase overall emergent plant cover in the pool.

Management actions taken to control emergent plant cover in the pool include lowering water levels in the winter and burning units within the pool on a 3-year or longer rotation. As noted above, however, the spillway structures do not allow complete draining of the pool. To document the effects of burning if complete dewatering can be achieved, an experimental sub-impoundment unit was constructed in the late 1980s. The unit was completely drained in the early 1990s and left in this state for 3 years; during this drawdown period, the sub-impoundment was periodically burned. Bryant (1996) determined that mean accretion in the pool was 540 percent greater than that in the drained unit and the nearby natural marsh during the period from 1963 to 1996. Chabreck (1997) concluded that the water manipulations and controlled burns in this unit were effective in reducing organic matter accumulation in the soil and increasing open water habitat.

Although perceptions are that the pool is gradually progressing to a habitat dominated by emergent vegetation despite management efforts, actual changes in the pool plant communities have not been documented. A possible direction of vegetation change in the pool consists of a shift in the overall cover of open water compared to emergent marsh, which can be documented through comparison of historical and recent aerial photography. A different trajectory of change may consist of shifts in plant community composition and structure. We address this latter situation in this study. Specifically, objectives were to (1) compare vegetation present in 2006 and 2007 to that found during a study conducted on Lacassine National Wildlife Refuge in 1973 (Fruge, 1974) to identify if vegetation change occurred in the pool over the intervening years, and (2) document if there was interannual variation in plant communities between 2006 and 2007.

\section{Methods}

\section{Study Area and Previous Study}

This study was conducted within the 6,475-ha impoundment at Lacassine National Wildlife Refuge (hereafter referred to as the pool) located in the Chenier Plain of Louisiana along the northern Gulf of Mexico. Because rainfall is essentially the only water source for the pool, freshwater conditions prevail unless higher salinity water is introduced during storm events from brackish marshes south of the pool or from the lower Mermentau River by way of Grand Lake. Abundant plant species in the pool include Panicum hemitomon, Sagittaria lancifolia, Nymphaea odorata, and Brasenia schreberi (Fruge 1974). The vegetation assemblage of the pool is typical of the fresh maidencane type described by Visser and others (2000), which composes about 17 percent of marsh areas in the Chenier Plain.

Vegetation in the pool was sampled in 1973 by Fruge (1974); hereafter, this will be called "the 1973 study." An overlay for the pool was divided into 40.5-ha sections for the 1973 study, and 14 of the sections were randomly selected. Three plots in emergent and floating-leaved/submersed vegetation communities were then randomly selected within each of the 14 sections. Therefore, 42 plots were located in each of the emergent and floating-leaved/submersed habitat types for a total of 84 sampling plots. A 0.5 -square meter $\left(\mathrm{m}^{2}\right)$ frame was used to sample vegetation in each plot. At emergent plots, sampling consisted of counting the number of stems for each species present and clipping all stems at the water surface for determination of fresh (samples were not dried) aboveground biomass. At the remaining plots, percent cover for floating-leaved species was estimated within the $0.5-\mathrm{m}^{2}$ frame. Plants were then harvested in a 929-square centimeter $\left(\mathrm{cm}^{2}\right)(30.5 \mathrm{~cm} \times 30.5 \mathrm{~cm})$ area by using oyster tongs, and the volume of submersed species was determined through water displacement. The combined fresh (sample not dried) biomass of all species was obtained for each plot. Plot-level data on species richness were not available for the 1973 study. 


\section{Data Collection}

This study was designed with the intent to duplicate as much as possible the sampling locations used in the 1973 study. By using the rough sketch of the 14 sections provided in the 1974 report, a geographic information system (GIS) was applied to find Universal Transverse Mercator (UTM) coordinates for the southwestern corner of each of the sections (fig. 1). To accomplish this, landscape features on the Fruge (1974) map were matched with the same features on a recent color infrared aerial photograph displayed by the GIS. The landscape features included levees, canals, and other water bodies. By placing a cursor on the monitor at the point identified as the southwestern corner of each
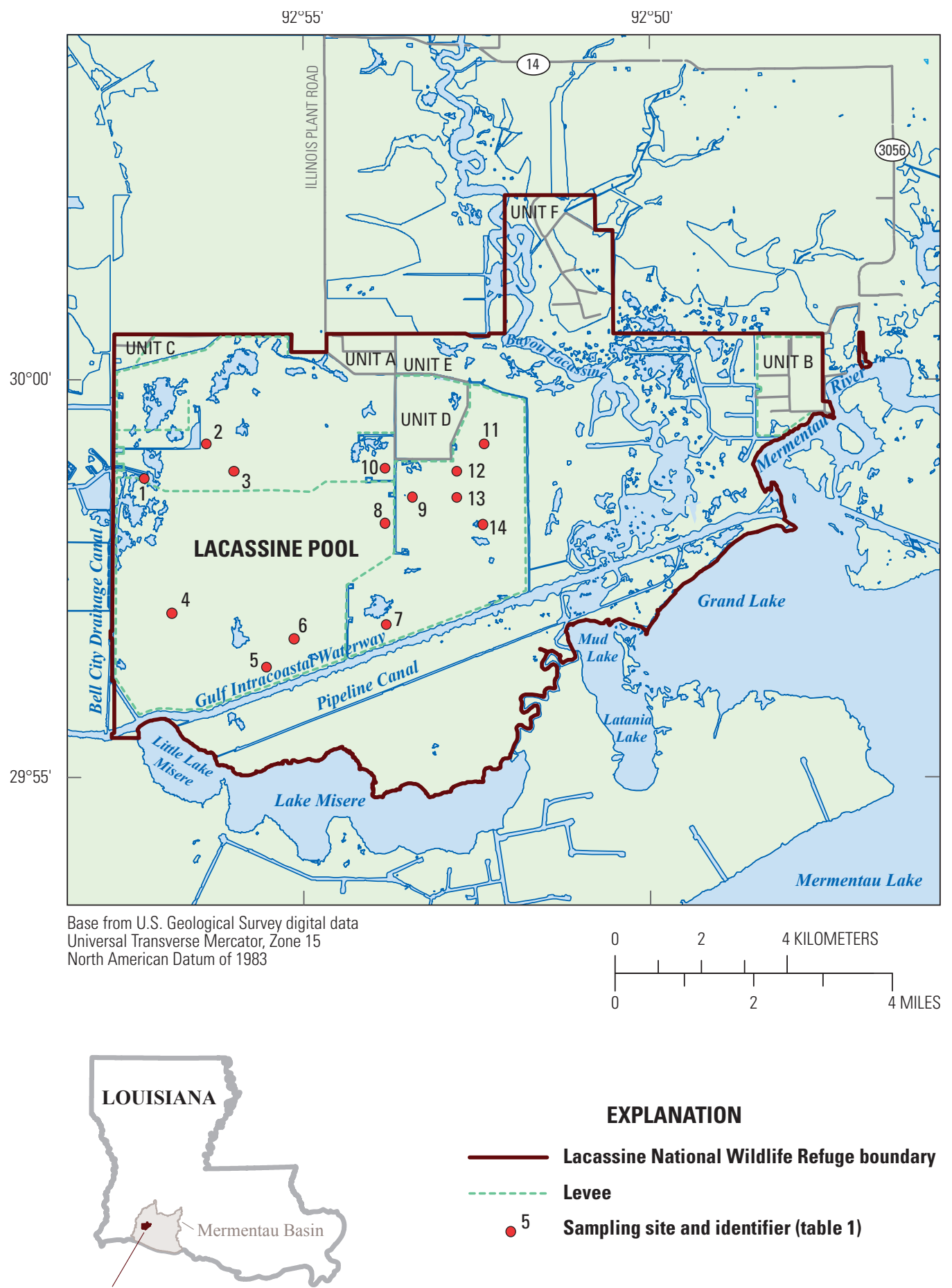

EXPLANATION

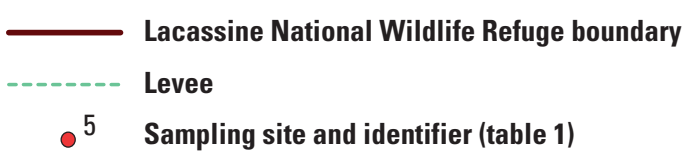

LACASSINE NATIONAL WILDLIFE REFUGE

Figure 1. Map of Lacassine National Wildlife Refuge, Louisiana. Points indicate the southwest corner of 14 sections in Lacassine pool with dimensions of $636 \times 636 \mathrm{~m}$. A total of six vegetation sampling plots was located within each section. 
40.5-ha $(636 \mathrm{~m} \times 636 \mathrm{~m})$ section, UTM coordinates for the points were generated by the GIS (table 1). Six sampling plots were randomly selected within each of the 14 sections, with three plots in areas with predominantly emergent plant species (designated EM) and three plots with submersed or floatingleaved vegetation or with open water lacking vegetation (designated submersed aquatic vegetation or SUB). A random numbers generator was used to generate a list of UTM coordinates for sites located randomly throughout each section and the points (coordinate pairs) were numbered serially. An airboat was used to visit each site on the list, starting with Point 1 . The site was designated as EM or SUB on the basis of vegetation present and became a sampling plot if the quota for that section had not been reached. When three plots of EM or SUB habitat were sampled, additional points of the same type were skipped over, and sampling continued until we had reached the desired quota of 3 EMs and 3 SUBs. Global Positioning System (GPS) locations of the sample plot centers were recorded in 2006 (appendix A), and the plots were relocated by using GPS in 2007. Similar to the 1973 study, a total of 84 plots was sampled with 42 plots in each of the two vegetation types.

Vegetation was sampled in July and August in 2006 and in August and September 2007. Sufficient details were not provided concerning the actual dimensions of the $0.5-\mathrm{m}^{2}$ frame

Table 1. Global Positioning System (GPS) locations for the southwestern corner of 14 sections established within Lacassine pool, Lacassine National Wildlife Refuge, Louisiana. Each section was 40.5 hectares ( $636 \times 636$ meters).

\begin{tabular}{ccc}
\hline Site & Easting & Northing \\
\hline 1 & 504355 & 3316490 \\
2 & 505790 & 3317287 \\
3 & 506427 & 3316650 \\
4 & 504992 & 3313372 \\
5 & 507187 & 3312115 \\
6 & 507825 & 3312770 \\
7 & 509977 & 3313094 \\
8 & 509944 & 3315454 \\
9 & 510579 & 3316069 \\
10 & 509944 & 3316723 \\
11 & 512237 & 3317295 \\
12 & 511603 & 3316660 \\
13 & 511603 & 3316044 \\
14 & 512218 & 3315430 \\
\hline
\end{tabular}

used in the 1973 study, so we assumed the frame was a square measuring $0.5 \mathrm{~m}$ on each side. Therefore, a $0.25-\mathrm{m}^{2}$ $(50 \mathrm{~cm} \times 50 \mathrm{~cm})$ quadrat was used to sample vegetation. The percent cover of each species present in the quadrat was estimated to the nearest 1 percent at each site; this technique was used in all habitat types. At plots with submersed vegetation, if vegetation could not be seen in the water column, a rake was used to collect samples and estimate cover of any species present. Salinity in plots with standing water was recorded. Response variables were total cover by species and species richness per plot; the Shannon diversity index $\left(\mathrm{H}^{\prime}\right)$ and evenness (J) (Kent and Coker, 1992) were also calculated for each of the 84 plots. The frequency of occurrence, calculated by dividing the number of plots where a species was found by the total number of plots, was determined.

\section{Statistical Analyses}

To compare vegetation in 1973 to that in 2006 and 2007, we used species frequency of occurrence at the sampling plots. The 1973 study identified 11 emergent species, four floatingleaved species, and eight submersed species (Fruge, 1974). We analyzed the two habitat types (EM, SUB) separately, so the 1973 data for floating-leaved and submersed species were combined into SUB habitat for the analyses. The total of 12 species in the habitat type SUB was then reduced to 9 for the following reason. The 1973 study identified four species of Utricularia (U. foliosa, U. gibba, U. inflata, and U. purpurea). Because flowers and seeds of Utricularia were often absent during the 2006 and 2007 surveys, this group of species was identified only to genus. The highest frequency occurrence of the four Utricularia species in 1973 was used in the analyses. Similarly, we identified most plants in the genus Hydrocotyle to species, whereas identification of these plants in the 1973 study stopped at the genus level. Therefore, all Hydrocotyle species ( $H$. ranunculoides, $H$. umbellata, and Hydrocotyle sp.) were lumped for the 2006 and 2007 datasets; because we had individual plot-level data (unlike the 1973 study), a true frequency was determined for this group of species. After reviewing type designation for 2006 and 2007, plots dominated by Eleocharis elongata, a species classified as a submersed species in the 1973 study, were changed from EM to SUB. A two-sample binomial was used to detect differences in frequency between the years within each vegetation type.

To determine if interannual variation existed between the 2006 and 2007 sampling events, several analyses were run; habitat type was not included in these analyses. Only species with frequency of occurrence equal to or greater than 0.05 (i.e., species found at four or more plots) were included for analyses of total cover by species and frequency. A paired t-test was used to compare total cover by species, richness, H', and $\mathrm{J}$, and a two-sample binomial test was used for analysis of frequency differences. A paired t-test was also used to compare salinity by plot between years. A significance level of 0.05 was used for all analyses. 


\section{Results}

During data collection in 2006 and 2007, 51 plant species were recorded in the pool (appendix B); of these, 14 were identified to genus only. An additional six plants could not be identified and were recorded as unknowns. Unknown species were included in calculations for species richness, $\mathrm{H}^{\prime}$ and $\mathrm{J}$. The frequency of occurrence for all species and percent total cover (summed across all plots) were calculated by year (table 2). Photographs of plots in each of the habitat types were taken (fig. 2).

Of the 20 species reported in the 1973 study that were used in the analysis to document change compared to more recent information, 10 were not found in 2006 and 6 were not found in 2007 (table 3). In the EM habitat type, Bacopa caroliniana $(P=0.0000)$, Eleocharis equisetoides $(P<0.0001)$, Leersia hexandra $(P=0.0142)$, Panicum hemitomon $(P=0.0183)$, and Sagittaria lancifolia

Table 2. Frequency and total cover of plant species identified in 2006 and 2007 in Lacassine pool, Lacassine National Wildlife Refuge, Louisiana. The number of plots in each year was 84 . Names in bold font are species with frequency of occurrence greater than or equal to 0.05 in either year included in analyses of total cover and frequency difference.

\begin{tabular}{|c|c|c|c|c|c|c|c|c|c|}
\hline \multirow[b]{2}{*}{ Species } & \multicolumn{2}{|c|}{ Frequency } & \multicolumn{2}{|c|}{ Total cover (percent) } & \multirow[b]{2}{*}{ Species } & \multicolumn{2}{|c|}{ Frequency } & \multicolumn{2}{|c|}{ Total cover (percent) } \\
\hline & 2006 & 2007 & 2006 & 2007 & & 2006 & 2007 & 2006 & 2007 \\
\hline Alternanthera philoxeroides & 0.01 & 0.01 & 2 & 10 & Lemna sp. & 0.02 & 0.04 & 3 & 11 \\
\hline Andropogon sp. & 0.02 & 0.01 & 11 & 20 & Ludwigia decurrens & 0.01 & 0.00 & 3 & 0 \\
\hline Bacopa caroliniana & 0.00 & 0.02 & 0 & 15 & Ludwigia grandifolia & 0.01 & 0.00 & 3 & 0 \\
\hline Boehmeria cylindrica & 0.00 & 0.01 & 0 & 3 & Ludwigia sp. 2 & 0.06 & 0.07 & 208 & 285 \\
\hline Ceratophyllum sp. & 0.00 & 0.02 & 0 & 70 & Ludwigia sp. 3 & 0.01 & 0.00 & 7 & 0 \\
\hline Crinum americanum & 0.00 & 0.01 & 0 & 20 & Nitella gracilis & 0.00 & 0.01 & 0 & 70 \\
\hline Cyperus odoratus & 0.00 & 0.05 & 0 & 85 & Nymphoides aquatica & 0.04 & 0.01 & 81 & 3 \\
\hline Cyperus sp. & 0.11 & 0.08 & 221 & 90 & Nymphaea mexicana & 0.01 & 0.01 & 5 & 4 \\
\hline Eleocharis equisitoides & 0.05 & 0.05 & 32 & 110 & Potamogeton pusillus & 0.00 & 0.01 & 0 & 5 \\
\hline Eleocharis flavescens & 0.14 & 0.12 & 863 & 815 & Potamogeton sp. & 0.00 & 0.05 & 0 & 175 \\
\hline Eleocharis sp. & 0.12 & 0.17 & 213 & 687 & Sagittaria lancifolia & 0.05 & 0.06 & 32 & 145 \\
\hline Eragrostis sp. & 0.01 & 0.00 & 2 & 0 & Sacciolepis sp. & 0.01 & 0.00 & 100 & 0 \\
\hline Eupatorium capillifolium & 0.01 & 0.05 & 15 & 50 & Sacciolepis striata & 0.07 & 0.24 & 84 & 1,109 \\
\hline Eupatorium sp. & 0.07 & 0.06 & 138 & 127 & Triadenum walteri & 0.00 & 0.01 & 0 & 10 \\
\hline Fuirena squarrosa & 0.01 & 0.05 & 3 & 48 & Typha sp. & 0.01 & 0.11 & 10 & 615 \\
\hline Habenaria repens & 0.01 & 0.00 & 1 & 0 & Utricularia sp. & 0.13 & 0.37 & 298 & 1,807 \\
\hline Ipomoea sp. & 0.01 & 0.00 & 75 & 0 & Unknown 6 & 0.00 & 0.01 & 0 & 30 \\
\hline Leersia hexandra & 0.00 & 0.02 & 0 & 9 & Unvegetated & 0.50 & 0.26 & 2,924 & 1,298 \\
\hline
\end{tabular}



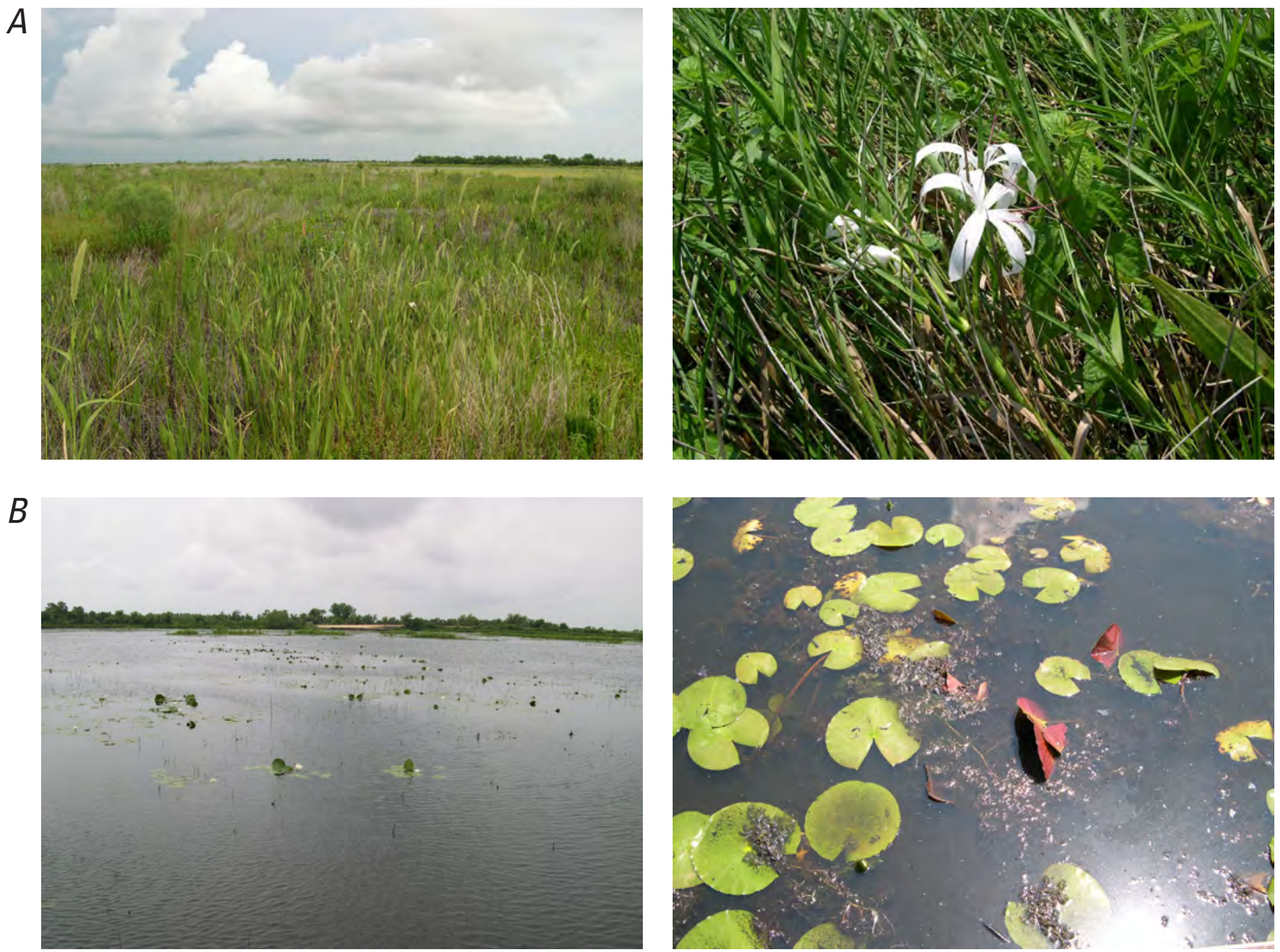

Figure 2. Photographs of the two habitat types designated in 2006 in Lacassine pool, Lacassine National Wildlife Refuge, Louisiana: emergent $(A)$ and submersed/floating leaved $(B)$.

$(P=0.0000)$ were significantly less frequent in 2006 compared to 1973. In the SUB habitat type, Brasenia schreberi $(P=0.0000)$, Cabomba caroliniana $(P=0.0086)$, Nitella gracilis $(P=0.0000)$, and Nymphoides aquatica $(P=0.0000)$ were also significantly less frequent in 2006 compared to 1973 . This pattern of lower frequency was also found when data from 1973 were compared to that from 2007 for these same species: Bacopa caroliniana $(P<0.0001)$, Eleocharis equisetoides $(P<0.0001)$, Leersia hexandra $(P=0.0449)$, Panicum hemitomon $(P<0.0001)$, Sagittaria lancifolia $(P=0.0000)$, Brasenia schreberi $(P=0.0000)$, Cabomba caroliniana $(P=0.0120)$, Nitella gracilis $(P=0.0000)$, and Nymphoides aquatica $(P=0.0000)$. When comparing these two years (1973 and 2007), we also found that the following three species were more frequent in 2007: Hydrocotyle sp. $(P=0.0000)$ and Sacciolepis striata $(P<0.0001)$ in EM habitat and Utricularia sp. $(P=0.0030)$ in SUB habitat.
A total of 21 species and unvegetated surface area occurred at a frequency greater than or equal to 0.05 in 2006 or 2007 (table 2); these species and unvegetated area were used for comparison of total mean cover and frequency of occurrence. Interannual variation was found when vegetation at the plots was compared between 2006 and 2007. Species richness in $2006(1.89 \pm 0.18$; all data presented as mean \pm 1 standard error) was lower $(P<0.0001)$ than that in 2007 $(3.08 \pm 0.21)$. The index H' was also lower $(P<0.001)$ in $2006(0.365 \pm 0.044)$ than in $2007(0.726 \pm 0.054)$, as was the value for $\mathrm{J}(P<0.0001)$ in $2006(0.366 \pm 0.041)$ compared to $2007(0.591 \pm 0.038)$. Mean total cover across all 84 plots did not differ for any of the species or for unvegetated surface area. The frequency of seven species and unvegetated surface differed between years (table 4); the frequency of all seven species was lower in 2006, whereas unvegetated surface frequency was higher. Surface-water salinity also differed between years $(P<0.0001, \mathrm{n}=62)$. Surface-water salinity in 
Table 3. Frequency of plants identified by Fruge (1974) in 1973 in Lacassine pool, Lacassine National Wildlife Refuge, Louisiana. Plants are listed by habitat type (EM equals emergent, SUB equals submersed or floating-leaved) with corresponding frequency in 2006 and 2007. Names of species with frequency that were significantly different $(P<0.05)$ between 1973 and 2006 (indicated by superscript $a$ ) or 1973 and 2007 (indicated by superscript $b$ ) are highlighted with bold font. Number of plots were as follows: 1973, EM and SUB equal 42; 2006, EM equals 39 and SUB equals 45; and 2007, EM equals 43 and SUB equals 41.

\begin{tabular}{|c|c|c|c|c|}
\hline \multirow[b]{2}{*}{ Habitat type } & \multirow[b]{2}{*}{ Species } & \multicolumn{3}{|c|}{ Frequency } \\
\hline & & 1973 & 2006 & 2007 \\
\hline \multicolumn{5}{|l|}{ EM } \\
\hline & Bacopa caroliniana $a^{a, b}$ & 0.43 & 0 & 0.05 \\
\hline & Bacopa monnieri & 0.02 & 0.05 & 0.02 \\
\hline & Cephalanthus occidentalis & 0.02 & 0 & 0 \\
\hline & Crinum americanum & 0.05 & 0 & 0.02 \\
\hline & Eleocharis equisitoides $^{a, b}$ & 0.36 & 0 & 0.02 \\
\hline & Hydrocotyle sp. ${ }^{b}$ & 0.10 & 0.18 & 0.65 \\
\hline & Leersia hexandra ${ }^{a, b}$ & 0.14 & 0 & 0.02 \\
\hline & Ludwigia sphaerocarpa & 0.02 & 0.03 & 0 \\
\hline & Panicum hemitomon ${ }^{a, b}$ & 0.79 & 0.54 & 0.30 \\
\hline & Sacciolepis striata ${ }^{b}$ & 0.07 & 0.15 & 0.47 \\
\hline & Sagittaria lancifolia ${ }^{a, b}$ & 0.88 & 0.10 & 0.09 \\
\hline \multicolumn{5}{|l|}{ SUB } \\
\hline & Brasenia schreberi ${ }^{a, b}$ & 0.79 & 0 & 0 \\
\hline & Cabomba caroliniana ${ }^{a, b}$ & 0.14 & 0 & 0 \\
\hline & Eleocharis elongata & 0.21 & 0.13 & 0.34 \\
\hline & Nelumbo lutea & 0.02 & 0 & 0 \\
\hline & Nitella gracilis ${ }^{a, b}$ & 0.55 & 0 & 0.02 \\
\hline & Nymphaea odorata & 0.45 & 0.47 & 0.56 \\
\hline & Nymphoides aquatica ${ }^{a, b}$ & 0.76 & 0.04 & 0 \\
\hline & Potamogeton pusillus & 0.05 & 0 & 0.07 \\
\hline & Utricularia sp. ${ }^{b}$ & 0.36 & 0.24 & 0.68 \\
\hline
\end{tabular}

$2006(1.78 \pm 0.14$ parts per thousand $(\mathrm{ppt}))$ was greater than that in $2007(0.80 \pm 0.04 \mathrm{ppt})$ at the 62 plots for which data for both years were available.

\section{Discussion}

\section{Vegetation Comparison Over Three Decades}

We identified a significantly lower frequency of occurrence in 2006 and 2007 compared to 1973 for 5 species in emergent habitats and 4 species in submersed habitats. Of the 9 species that differed, 6 species were not found at the sampling plots in 2006; 3 of the 9 were absent in 2007 and 4 were found in only 1 or 2 plots (table 3 ). It is interesting to
Table 4. Significant results of a two-sample binomial test of species frequency, Lacassine pool, Lacassine National Wildlife Refuge, Louisiana, in 2006 and 2007. Other species were not significant at $P \leq 0.05$. Difference equals frequency 2006 minus frequency 2007; data for frequency by year appear in table 2 .

\begin{tabular}{lcc}
\hline \multicolumn{1}{c}{ Species } & Difference between years & $\boldsymbol{P}$ \\
\hline Cyperus odoratus & -0.048 & 0.043 \\
Eleocharis elongata & -0.119 & 0.022 \\
Hydrocotyle umbellata & -0.238 & 0.000 \\
Potamogeton sp. & -0.048 & 0.043 \\
Sacciolepis striata & -0.167 & 0.003 \\
Typha sp. & -0.095 & 0.009 \\
Utricularia sp. & -0.238 & 0.000 \\
Unvegetated surface & 0.238 & 0.001 \\
\hline
\end{tabular}


note that the frequency of 2 species that have been a focus of concern as the primary species spreading within the pool, Panicum hemitomon and Sagittaria lancifolia, was actually lower in 2006 and 2007 compared to 1973. The absence of Brasenia schreberi in plots in 2006 and 2007, however, may be of some concern. The seeds of this species are an important food source for waterfowl (Fassett, 1957; Stutzenbaker, 1999). Unpublished records from Lacassine National Wildlife Refuge indicate that Brasenia schreberi was planted in Lacassine pool in 1943 and is mentioned as a dominant species among floating-leaved vegetation in unpublished reports periodically through the 1970s. The absence of this species in plots in 2006 and 2007 may indicate an overall decline in the population. The three species with significantly higher frequency in 2007 compared to 1973 (Hydrocotyle sp., Sacciolepis striata and Utricularia sp.) have little wildlife habitat value (Stutzenbaker, 1999).

We found comparison of 2006 and 2007 data to the 1973 dataset to be problematic. Difference in species richness between years could not be examined because plot-level data for the 1973 study were not available. Even if these data had been available, an account of species richness in the 1973 study would be somewhat suspect. Although Fruge (1974) compiled a list of all species encountered across the entire pool during the 1973 study, a list that consisted of 138 species, detailed information for only 23 species was reported for the sample plots. In comparison, 34 species were identified in plots in 2006 and 50 in 2007, including 6 species identified as unknown. It is therefore uncertain if all species were actually recorded by Fruge (1974), or if only species of particular interest at the time were included. Also, because information on the location of the 1973 plots (for example, latitude and longitude, proximity to a landmark) was not provided, it is not possible to speculate how close the 2006 and 2007 sample plots were to those used in the 1973 study. Differences identified may, therefore, be attributable to difference between plots rather than between plant communities.

\section{Interannual Variation in Plant Communities}

There was a significant increase in species richness from 2006 to 2007, with a concurrent decrease in the amount of unvegetated surface areas from 2006 to 2007 . The Shannon diversity index, which combines information on species richness and evenness, and the evenness index itself, indicated that the plant community in 2007 was more diverse and more evenly distributed than in 2006. These combined results offer compelling evidence that significant interannual variation in plant communities existed, even though total cover by species did not vary. Because just 2 years of data are available, however, it is not possible to determine if this degree of interannual variation is unusual or if it is normal.

It is important to note that Lacassine National Wildlife Refuge was in the path of Hurricane Rita in the fall of 2005 , and disturbance from the storm probably affected vegetation in the pool. Hurricane Rita, which made landfall west of Johnsons Bayou near the Texas-Louisiana border on September 24, 2005, as a Category 3 storm (Saffir-Simpson Hurricane Wind Scale), created a storm surge of up to $4.6 \mathrm{~m}$ in southwestern Louisiana and flooded areas up to $40 \mathrm{~km}$ from the coast (Farris and others, 2007). Neyland (2007) conducted a survey documenting the presence of aquatic plant species in Cameron Parish, southwestern Louisiana, in June 2005 and June 2006, 9 months after Hurricane Rita made landfall. Neyland's study included an area south of the Gulf Intracoastal Waterway (GIWW), called the southern sector, and an area north of the GIWW that included the southern part of Lacassine National Wildlife Refuge, called the Lacassine sector (Neyland, 2007). Devastating impacts from Hurricane Rita were documented in the southern sector, with elimination of all but 3 of the 31 species identified in June 2005. This loss was attributed to salt burn and scour from tidal surge that physically removed vegetation (Neyland, 2007). Of 30 species identified in 2005 in the Lacassine sector, however, only 1 species was absent in the 2006 survey. Neyland (2007) concluded that the GIWW provided a barrier to protect the Lacassine sector from salt burn and scour.

Despite the conclusions reached by Neyland (2007), it is important to note that hurricanes can affect plant community attributes other than simple presence and absence of species. Salinity increases that are nonlethal to some species can nonetheless impact plant species vigor, cover, density, and distribution. Although recorded data are not available, personnel at Lacassine National Wildlife Refuge did in fact note that the surge associated with Hurricane Rita increased salinity in Lacassine pool (W. Syron, Lacassine National Wildlife Refuge, oral commun., March 2, 2011). Because there is no freshwater flowing through the pool, brackish or saltwater introduced by surges cannot be immediately flushed out. It is possible, therefore, that increased salinity levels may persist for some time in the pool. Gradually, however, the salts would have been diluted by distribution across the pool from the point of introduction and by rainfall, and eventually removed by draining through the water-control structures. Prior to Hurricane Rita, salinity in the pool was measured from January 2004 until February 2005 by two continuous recorders deployed at $50 \mathrm{~cm}$ below the marsh surface; these data indicate that salinity at this depth never exceeded 0.1 ppt (Howard, 2005a). In August 2006 we recorded pool surface-water salinities up to $4.8 \mathrm{ppt}$; the highest salinity recorded in 2007 was $2.1 \mathrm{ppt}$. Although surface salinity varied significantly between years, this difference may be related to weather events such as drought or rainfall and may, therefore, be of short duration. Such ephemeral changes cannot be reliably used to investigate trends. Rainfall records from the Lake Charles Regional Airport in Lake Charles, Louisiana, located about $30 \mathrm{~km}$ northwest of the refuge, indicated that there were two major events in July 2006 when total precipitation exceeded $12 \mathrm{~cm}$ (fig. 3; data from Weather Underground, 2011). For comparison, the highest rainfall level measured within a single $24-\mathrm{hr}$ period in 2007 was $8.5 \mathrm{~cm}$ 
(fig. 3). However, total annual precipitation in 2007, at $161.7 \mathrm{~cm}$, exceeded that in 2006, when total precipitation was $128.4 \mathrm{~cm}$ (Weather Underground, 2011). An additional issue to consider is that surface water salinity changes may not be reflected in soil pore waters. If pool salinity had been increased by the storm surge associated with Hurricane Rita and was then diluted through the processes described above, there may not have been sufficient time for the higher salinity water to move into the sediments and affect plant growth.

Assuming an increase in salinity in some parts of the pool in the fall of 2005 following Hurricane Rita, several factors would influence the ability of plants to recover. These factors include the degree of salinity stress, the depth and duration of flooding, and the depth of sediment or wrack deposited (Guntenspergen and others, 1995). Vegetation recovery in freshwater impoundments has been noted to be problematic if the impoundments cannot be flushed following saltwater inundation (Meeder, 1987). Although the dominant plant species in the pool are perennial and reproduced primarily by clonal spread, it is possible that some regeneration by seed occurs. A study by Middleton (2009) demonstrated that hurricanes may have a greater impact on regeneration by seed in freshwater marshes than in saltwater marshes. It can be speculated that the interannual variation in plant communities documented was caused by plants recovering from salinity stress as the pool gradually reverted to fresher conditions, but data over a longer timeframe are needed before this conclusion can be substantiated.

Fruge (1974) noted that Panicum hemitomon and Sagittaria lancifolia were the dominant species in the emergent plant community in 1973 (table 3). Data from our study indicated that although Panicum hemitomon cover remained high in the pool, Sagittaria lancifolia was not a dominant species in 2006 or 2007 . We found species in the genus Eleocharis (E. elongata, E. equisetoides, and E. flavescens) to be relatively common on sample plots. It is interesting to note that Eleocharis elongata is included on the list of rare plants in Louisiana. It has an assigned category of S3, defined as "rare and local throughout the State or found locally (even abundantly at some of its locations) in
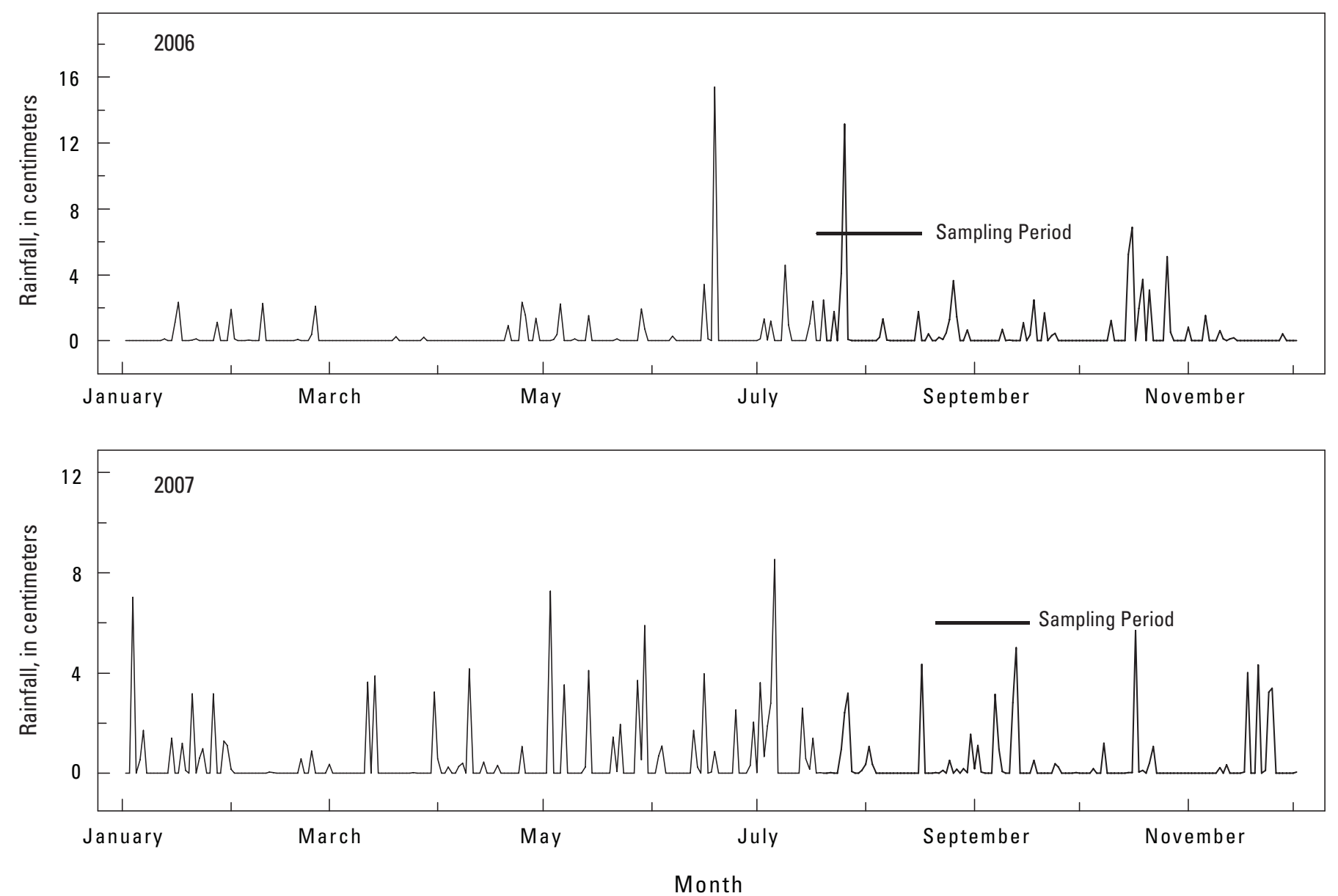

Figure 3. Daily rainfall at Lake Charles Regional Airport, Lake Charles, Louisiana, in 2006 and 2007 with sampling period each year indicated. Lake Charles Regional Airport is approximately $30 \mathrm{~km}$ northwest of Lacassine National Wildlife Refuge. Note that the scale of the $y$ axes differs. 
a restricted region of the State, or because of other factors making it vulnerable to extirpation (21 to 100 known extant populations)" (Louisiana Natural Heritage Program, 2011). A study conducted in 2003 in the pool indicated that Sagittaria lancifolia was relatively abundant at that time (Howard, 2005b). In that study, a systematic sampling scheme applied across the entire pool included 97 plots; the frequency of occurrence for Sagittaria lancifolia was 0.36. Species more commonly encountered than Sagittaria lancifolia in the 2003 study and their associated frequency were Panicum hemitomon (0.61), Utricularia sp. (0.49), Nymphoides aquatica (0.42), Nymphaea odorata (0.41), and Eleocharis equisetoides (0.39) (Howard, 2005b). It is unlikely that increased salinity levels associated with Hurricane Rita affected Sagittaria lancifolia to a greater extent than Panicum hemitomon given that the latter species is less tolerant of salinity than the former (Howard and Mendelssohn, 1999). Therefore, it is believed that the decreased occurrence of Sagittaria lancifolia and increased occurrence of species of Eleocharis may be indicative of a long-term trend in the pool. Future studies to evaluate the abundance of these species are required to determine if this trend continues.

\section{Summary}

A decrease in the frequency of occurrence for 9 plant species in Lacassine pool in 2006 and 2007 compared to observations from 1973 was documented in this study; 3 species were found to occur more frequently in 2007 compared to 1973. Half of the 20 species found in the 1973 study (4 Utricularia species were combined for the analysis) were not present in sample plots in 2006 and 6 were not present in 2007. However, more species were identified than were found in the 1973 study with 34 species identified in 2006 and 50 species in 2007; 23 species were identified in 1973. It is difficult to make strong conclusions about longterm changes because some of the data were not directly comparable. Plant species abundance in emergent plots in 1973 was determined by stem counts, whereas we estimated percentage of cover by species. Precise locations for the sites sampled in 1973 were not available, and the difference in species frequency may be due to plot differences rather than actual differences in vegetation. However, it was clear that there was interannual variation in plant communities between 2006 and 2007. Increased species richness and frequency of seven species along with decreased area of unvegetated surface indicated change in the plant community structure. Although it can be speculated that differences may have been caused by a gradual decrease in salinity in the pool through the second growing season following Hurricane Rita, long-term data are required to determine if changes documented were actually outside of normal variation.

\section{References Cited}

Bryant, J.C., 1996, Effects of structural marsh management on marsh vertical accretion: Baton Rouge, La., Louisiana State University, M.S. thesis, 90 p.

Callaway, J.C., Nyman, J.A., and DeLaune, R.D., 1996, Sediment accretion in coastal wetlands: A review and a simulation model of processes: Current Topics in Wetland Biogeochemistry, v. 2, p. 2-23.

Chabreck, R.H., 1997, Experimental dewatering of Unit D on Lacassine National Wildlife Refuge: Final report to the U.S. Fish and Wildlife Service, Lacassine National Wildlife Refuge, Lake Arthur, La., 19 p.

Farris, G.S., Smith, G.L., Crane, M.P., Demas, C.R., Robbins, L.L., and Lavoie, D.L., eds., 2007, Science and the storms - the USGS response to the hurricanes of 2005: U.S. Geological Survey Circular 1306, 283 p.

Fassett, N.C., 1957, A manual of aquatic plants: Madison, Wis., University of Wisconsin Press, 405 p.

Fruge, D.W., 1974, The vegetation of Lacassine Pool, Lacassine National Wildlife Refuge, Louisiana: Lafayette, La., U.S. Fish and Wildlife Service, 51 p.

Guntenspergen, G.R., Cahoon, D.R., Grace, J., Steyer, G.D., Founet, S., Townson, M.A., and Foote, A.L., 1995, Disturbance and recovery of the Louisiana coastal marsh landscape from the impacts of Hurricane Andrew: Journal of Coastal Research, v. SI21, p. 324-339.

Howard, R.J., 2005a, Sedimentation, elevation and water level change in Lacassine Pool, Lacassine National Wildlife Refuge: Final report submitted to the U.S. Fish and Wildlife Refuge, Lacassine National Wildlife Refuge, Lake Arthur, La., 13 p.

Howard, R.J., 2005b, Evaluation of the soils of Lacassine National Wildlife Refuge - profile of organic and mineral layers as related to elevation: Final report submitted to the U.S. Fish and Wildlife Refuge, Lacassine National Wildlife Refuge, Lake Arthur, La., 15 p.

Howard, R.J., and Mendelssohn, I.A., 1999, Salinity as a constraint on growth of oligohaline marsh macrophytes. I. Species variation in stress tolerance: American Journal of Botany, v. 86, p. 785-794.

Kent, M., and Coker, P., 1992, Vegetation description and analysis, a practical approach: New York, John Wiley and Sons, $363 \mathrm{p}$. 
Louisiana Natural Heritage Program, 2011, Rare plant species: Department of Wildlife and Fisheries, accessed June 3, 2011, at http://www.wlf.louisiana.gov/wildlife/rareplant-species.

Meeder, J.F., 1987, Variable effects of hurricanes on the coast and adjacent marshes - a problem for land managers: Proceedings of the Water Quality and Wetland Management Conference, New Orleans, Louisiana, v. 4, p. 337-374.

Middleton, B.A., 2009, Regeneration of coastal marsh vegetation impacted by Hurricanes Katrina and Rita: Wetlands, v. 29 , p. $54-65$.

Mitsch, W.J., and Gosselink, J.G., 2007, Wetlands (4th ed.): New York, John Wiley and Sons, 582 p.

Neyland, R., 2007, The effects of Hurricane Rita on the aquatic vascular flora in a large fresh-water marsh in Cameron Parish, Louisiana: Castanea, v. 72, p. 1-7.
Nyman, J.A., DeLaune, R.D., Roberts, H.H., and Patrick, W.H., Jr., 1993, Relationship between vegetation and soil formation in a rapidly submerging coastal marsh: Marine Ecology and Progress Series, v. 96, p. 269-279.

Stutzenbaker, C.D., 1999, Aquatic and wetland plants of the western Gulf Coast: Austin, Tex., Texas Parks and Wildlife Press, $465 \mathrm{p}$.

Visser, J.M., Sasser, C.E., Linscombe, R.G., and Chabreck, R.H., 2000, Marsh vegetation types of the Chenier Plain, Louisiana, USA: Estuaries, v. 23, p. 318-327.

Weather Underground, 2011, History for Lake Charles Regional, LA: accessed June 1, 2011, at http://www. wunderground.com/history/airport/KLCH/. 



\section{Appendix 1.}

Table 1-1. Global Positioning System (GPS) locations of 84 plots established in Lacassine pool, Lacassine National Wildlife Refuge, Louisiana, for vegetation sampling, 2006.

\begin{tabular}{|c|c|c|c|c|c|c|c|}
\hline Site & Plot Number & Easting & Northing & Site & Plot Number & Easting & Northing \\
\hline \multirow[t]{6}{*}{1} & 1 & 504530 & 3316565 & 8 & 1 & 510469 & 3316029 \\
\hline & 2 & 504930 & 3316915 & & 2 & 510219 & 3315479 \\
\hline & 3 & 504730 & 3316715 & & 3 & 510069 & 3315679 \\
\hline & 4 & 504780 & 3316965 & & 4 & 510019 & 3315579 \\
\hline & 5 & 504480 & 3316615 & & 5 & 510369 & 3315629 \\
\hline & 11 & 504380 & 3316765 & & 14 & 510319 & 3315529 \\
\hline \multirow[t]{6}{*}{2} & 1 & 505915 & 3317412 & 9 & 1 & 511104 & 3316644 \\
\hline & 2 & 505965 & 3317306 & & 2 & 510904 & 3316444 \\
\hline & 3 & 505965 & 3317562 & & 3 & 511104 & 3316544 \\
\hline & 4 & 506365 & 3317812 & & 4 & 510904 & 3316394 \\
\hline & 5 & 506115 & 3317762 & & 5 & 510654 & 3316294 \\
\hline & 6 & 505865 & 3317862 & & 10 & 510804 & 3316194 \\
\hline \multirow[t]{6}{*}{3} & 1 & 506852 & 3317225 & 10 & 1 & 510069 & 3317148 \\
\hline & 2 & 507002 & 3317225 & & 2 & 510469 & 3317298 \\
\hline & 3 & 506452 & 3316675 & & 3 & 510419 & 3310798 \\
\hline & 7 & 506502 & 3317025 & & 4 & 510469 & 3317198 \\
\hline & 9 & 506702 & 3317025 & & 5 & 510219 & 3316898 \\
\hline & 12 & 506502 & 3316775 & & 6 & 510019 & 3316848 \\
\hline \multirow[t]{6}{*}{4} & 1 & 505317 & 3313597 & 11 & 1 & 512812 & 3317670 \\
\hline & 2 & 505517 & 3313397 & & 2 & 512712 & 3317620 \\
\hline & 3 & 505117 & 3313547 & & 3 & 512262 & 3317420 \\
\hline & 4 & 505067 & 3313497 & & 4 & 512462 & 3317670 \\
\hline & 5 & 505567 & 3313597 & & 5 & 512562 & 3317520 \\
\hline & 30 & 505567 & 3313547 & & 12 & 512312 & 3317420 \\
\hline \multirow[t]{6}{*}{5} & 1 & 507412 & 3312190 & 12 & 1 & 511828 & 3317035 \\
\hline & 2 & 507512 & 3312340 & & 2 & 512128 & 3316685 \\
\hline & 3 & 507762 & 3312690 & & 3 & 511728 & 3317235 \\
\hline & 5 & 507312 & 3312490 & & 7 & 511628 & 3316885 \\
\hline & 15 & 507562 & 3312190 & & 14 & 512128 & 3316735 \\
\hline & 18 & 507462 & 3312240 & & 15 & 512078 & 3317085 \\
\hline \multirow[t]{6}{*}{6} & 1 & 507950 & 3313295 & 13 & 1 & 511678 & 3316469 \\
\hline & 2 & 508300 & 3313145 & & 2 & 511778 & 3316569 \\
\hline & 3 & 508200 & 3313195 & & 4 & 511878 & 3316519 \\
\hline & 4 & 508150 & 3313095 & & 8 & 512128 & 3316519 \\
\hline & 5 & 508400 & 3313145 & & 19 & 511978 & 3316619 \\
\hline & 14 & 507900 & 3312895 & & 20 & 512128 & 3316569 \\
\hline \multirow[t]{6}{*}{7} & 1 & 510302 & 3313269 & 14 & 1 & 512343 & 3315755 \\
\hline & 2 & 510252 & 3313269 & & 2 & 512693 & 3315705 \\
\hline & 3 & 510002 & 3313119 & & 3 & 512543 & 3315905 \\
\hline & 4 & 510502 & 3313269 & & 4 & 512493 & 3316005 \\
\hline & 6 & 510452 & 3313419 & & 6 & 512343 & 3315555 \\
\hline & 7 & 510052 & 3313319 & & 7 & 512393 & 3315505 \\
\hline
\end{tabular}




\section{Vegetation of Lacassine National Wildlife Refuge, Louisiana}

\section{Appendix 2.}

Table 2-1. Plants identified in 0.25-square meter quadrats at Lacassine pool, Lacassine National Wildlife Refuge, Louisiana, from July to September, 2006 or 2007.

[Two unknown species in the genus Ludwigia were found]

\begin{tabular}{lcc}
\hline Scientific name & Family & Common name \\
\hline & Algae & \\
Nitella gracilis (J.E.Smith) C.Agardh & Characeae & slender stonewort \\
\hline & & \\
\hline
\end{tabular}

\section{Typhaceae}

Typha L.

Potamogeton pusillus L.

Potamogeton L.

Sagittaria lancifolia L.

Limnobium spongia (Bosc) Rich. ex Steud.

Andropogon glomeratus (Walter) Britton, Sterns \& Poggenb.

Andropogon L.

Echinochloa crus-galli (L.) P. Beauv.

Eragrostis von Wolf

Leersia hexandra Sw.

Panicum hemitomon Schult.

Sacciolepis Nash

Sacciolepis striata (L.) Nash

Cyperus L.

Cyperus odoratus L.

Eleocharis elongata Chapm.

Eleocharis equisetoides (Elliot) Torr.

Eleocharis flavescens (Poir.) Urb.

Eleocharis R. Br.

Fuirena squarrosa Michx.

Lemna L.

Xyris ambigua Bey. ex Kunth

Heteranthera reniformis Ruiz \& Pav.

Crinum americanum L.

Habenaria repens Nutt. cattail

Potamogetonaceae

small pondweed

pondweed

Alismataceae

bulltongue arrowhead

Hydrocharitaceae

Poaceae

spongeplant

bushy bluestem

bluestem

barnyardgrass

lovegrass

southern cutgrass

maidencane

cupscale grass

American cupscale

Cyperaceae

flatsedge

fragrant flatsedge

slim spikerush

jointed spikesedge

yellow spikerush

spikerush

dwarf umbrella-sedge

Lemnaceae

duckweed

Xyridaceae

Pontederiaceae

Liliaceae

Orchidaceae kidneyleaf mudplantain

American crinum

waterspider bog orchid 
Table 2-1. Plants identified in 0.25-square meter quadrats at Lacassine pool, Lacassine National Wildlife Refuge, Louisiana, from July to September, 2006 or 2007.-Continued

[Two unknown species in the genus Ludwigia were found]

\begin{tabular}{|c|c|c|}
\hline Scientific name & Family & Common name \\
\hline \multicolumn{3}{|c|}{ Dicots } \\
\hline & Lythraceae & \\
\hline \multirow[t]{2}{*}{ Decodon verticillatus (L.) Elliot } & & swamp loosestrife \\
\hline & Urticaceae & \\
\hline \multirow[t]{2}{*}{ Boehmeria cylindrica (L.) Sw. } & & smallspike false nettle \\
\hline & Amaranthaceae & \\
\hline \multirow[t]{2}{*}{ Alternanthera philoxeroides (Mart.) Griseb. } & & alligatorweed \\
\hline & Ceratophyllaceae & \\
\hline \multirow[t]{2}{*}{ Ceratophyllum L. } & & hornwort \\
\hline & Clusiaceae & \\
\hline \multirow[t]{2}{*}{ Hypericum hypericoides (L.) Crantz ssp. hypericoides } & & St. Andrew's cross \\
\hline & Nymphaeaceae & \\
\hline Nymphaea mexicana Zucc. & & yellow waterlily \\
\hline \multirow[t]{2}{*}{ Nymphaea odorata Aiton } & & American white waterlily \\
\hline & Menyanthaceae & \\
\hline \multirow[t]{2}{*}{ Nymphoides aquatica (J.F. Gmel.) Kuntze } & & big floatingheart \\
\hline & Clusiaceae & \\
\hline \multirow[t]{2}{*}{ Triadenum walteri (J.G. Gmel.) Gleason } & & greater marsh St. Johnswort \\
\hline & Onagraceae & \\
\hline Ludwigia decurrens Walter & & wingleaf primrose-willow \\
\hline Ludwigia grandiflora (Michx.) Greuter \& Burdet ssp. grandiflora & & large-flower primrose-willow \\
\hline Ludwigia $\mathrm{L}$. & & primrose-willow \\
\hline \multirow[t]{2}{*}{ Ludwigia sphaerocarpa Elliot } & & globefruit primrose-willow \\
\hline & Apiaceae & \\
\hline Hydrocotyle $\mathrm{L}$. & & pennywort \\
\hline Hydrocotyle ranunculoides $\mathrm{L}$. $\mathrm{f}$. & & floating marshpennywort \\
\hline \multirow[t]{2}{*}{ Hydrocotyle umbellata $\mathrm{L}$. } & & manyflower marshpennywor \\
\hline & Araceae & \\
\hline \multirow[t]{2}{*}{ Peltandra virginica (L.) Schott } & & green arrow arum \\
\hline & Convolvulaceae & \\
\hline Ipomoea $\mathrm{L}$. & & morning-glory \\
\hline \multirow[t]{2}{*}{ Ipomoea sagittata Poir. } & & saltmarsh morning-glory \\
\hline & Scrophulariaceae & \\
\hline Bacopa caroliniana (Walter) B.L. Rob. & & blue waterhyssop \\
\hline \multirow[t]{2}{*}{ Bacopa monnieri (L.) Pennell } & & herb of grace \\
\hline & Lentibulariaceae & \\
\hline \multirow[t]{2}{*}{ Utricularia $\mathrm{L}$. } & & bladderwort \\
\hline & Asteraceae & \\
\hline Eupatorium capillifolium (Lam.) Small & & dogfennel \\
\hline Eupatorium L. & & thoroughwort \\
\hline
\end{tabular}


Publishing support provided by the Lafayette Publishing Service Center 


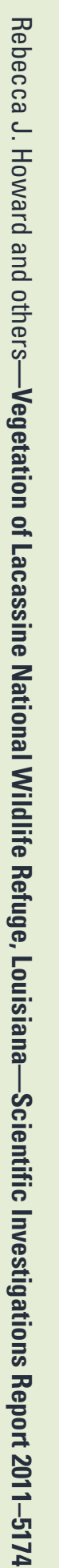

